УЯВЛЕННЯ ПРО ВИЩІ ПРОЯВИ ПСИХІЧНОГО РОЗВИТКУ У ФІЛОСОФСЬКІЙ ПСИХОЛОГІї КІНЦЯ XIX - ПОЧАТКУ XХ СТОЛІТЬ

\author{
IDEAS ABOUT HIGHER MANIFESTATIONS \\ OF MENTAL DEVELOPMENT IN PHILOSOPHICAL PSYCHOLOGY \\ OF THE END OF XIX - EARLY XX CENTURY
}

\begin{abstract}
Стаття присвячена з'ясуванню загальних тенденцій щодо розуміння початку морального життя в людині. Аналіз наукових джерел учених дає змогу стверджувати, що представниками київської школи фрілософрської психології кінця ХIX - поч. XX cm., зокрема С.С. Гогоцьким, I.O. Сікорським, Г.І. Челпановим і В.В. Зеньковським, наголошується, що вищі й нижчі схильності $\epsilon$ вродженими. На моральне життя здійснює вплив спадковість. Ідеться не про моральну свідомість, котра ще не може сорормуватися протягом першого року життя, а про такі психічні прояви, які лише підготовляють матеріал для морального життя, які лише у світлі моральної свідомості, що сорормувалася, виявляють у собі вищі або нижчі прагнення. Згідно з поглядами вчених, на першому році життя можна спостерігати прояви заздрості, ревнощів, гніву, егоїзу, жорстокості - елементарну, зародкову моральну свідомість у формі «моралі почуття». Виникнення моральної свідомості в жодному разі не може бути зведено до впливів дії соціального середовища; незважаючи на те що весь соціальний досвід дитини має величезний вплив на зміст уявлень і понять, сама ффункція моральної свідомості не могла б виникнути в такому порядку. Духовне життя починає фрункціонувати в психіці у формі суто емоційного передування майбутнім вищим проявам психіки. 3 фрілософрсько-психологічних позицій моральне життя в дитині починається до формування моральної свідомості. Завдяки спадковості дитина народжується із цілою низкою нахилів, які визначають будову особистості, їі активність; соціальна взаємодія вперше виявляє перед дитиною об'єктивні відлуння їі активності. У фрілософрській психології вважається, що саме реакції навколишніх людей надають дитині матеріал, на якому усвідомлюється полярність вищого й нижчого. Моральна свідомість у повній паралелі із самосвідомістю формується як проєктивне, але вона не творить себе одним сочіальним досвідом. Матеріалом для формування моральної свідомості дитини слугують безпосередні реакції навколишніх людей на ї̈ поведінку.
\end{abstract}

DOI https://doi.org/10.32843/2663

5208.2020.13-1.19

\section{Мельник О.А.}

докторант кафедри психології розвитку факультету психології

Київський національний університет

імені Тараса Шевченка
Ключові слова: психіка, вищий розвиток психіки, моральна свідомість, духовний розвиток.

The article is devoted to elucidating general trends in understanding the beginning of moral life in man. Analysis of scientific sources of scientists suggests that the representatives of the Kiev school of philosophical psychology of the late nineteenth - early. In the twentieth century, in particular, S.S. Gogotsky, I.O. Sikorsky, G.I. Chelpanov and V.V. Zenkovsky, higher and lower tendencies are innate. Moral life is influenced by heredity. It is not a question of moral consciousness, which cannot yet be formed during the first year of life, but of such mental manifestations which only prepare material for moral life, which only in the light of the formed moral consciousness show higher or lower aspirations. According to scientists, it has been established that in the first year of life one can observe manifestations of envy, jealousy, anger, selfishness, cruelty - elementary, embryonic moral consciousness in the form of "morality of feeling". The emergence of moral consciousness in no case can be reduced to the influences of the social environment; despite the fact that the whole social experience of the child has a huge impact on the content of ideas and concepts, but the very function of moral consciousness could not arise in this order. Spiritual life begins to function in the psyche in the form of a purely emotional prelude to future higher manifestations of the psyche. From a philosophical and psychological standpoint, moral life in a child begins to form a moral consciousness. Due to heredity, a child is born with a number of inclinations that determine the structure of personality, its activity; social interaction for the first time reveals to the child objective echoes of its activity. In philosophical psychology, it is believed that it is the reactions of others that provide the child with material on which the polarity of the higher and lower is realized. Moral consciousness, in full parallel with self-consciousness, is formed as projective, but it does not create itself as a single social experience. The material for the formation of the child's moral consciousness are the direct reactions of others to his behavior. Key words: psyche, higher development of the psyche, moral consciousness, spiritual development
Постановка проблеми. Перетворення в соціальному, політичному та економічному житті сучасного українського суспільства вплинули на стратегію освіти як головного фактору прогресу й розвитку країни, посилення їі наукового, культурного та духовного потенціалу. Новими реаліями, характерними для сучасної науки загалом і психології зокрема, є тенденції її гуманітаризації, розгляд наукової думки в контексті соціально-культурних процесів, зростання ролі суб'єктного складника пізнавальної діяльності як підґрунтя інтеграції різних галузей знання в цільному вивченні людини.

Особливої уваги в період розвитку науки вимагає протидія неконструктивній критиці результатів попередніх етапів розвитку науки, неаргументованому запереченню традиційних методологічних підходів і принципів організації наукового дослідження, які можуть призвести до руйнування цілісності психологічного 
пізнання та наступності в його розвитку. Становлення наукового напряму в обов'язковому порядку має свої джерела й підґрунтя, проходить визначені етапи. Філософський етап розвитку психології - це найважливіший період формування теоретичних передумов перетворення психології в самостійну науку.

Постановка завдання. Мета статті з'ясувати загальні тенденції щодо розуміння початку морального життя в людині.

Виклад основного матеріалу дослідження. Жодний етап розвитку психологічної науки не володіє такими глибинними знаннями, що стосуються вищих проявів психічного, як філософській період. Наукові погляди представників київської школи філософської психології кінця XIX - поч. XX ст. є цьому підтвердженням. Згідно з ідеалістичним поглядом, вродженим у дитини визнається прагнення до добра, вищих цінностей, зводячи всі нижчі прояви психіки до впливів зовнішнього середовища. Проте у філософській психології вродженими варто вважати і вищі, і нижчі схильності. Цей погляд підтримується представниками київської школи філософської психології кінця XIX - поч. XX ст., зокрема С.C. Гогоцьким [1], І.О. Сікорським [6], Г.І. Челпановим [7] і В.В. Зеньковським [4], і вважається близьким до дійсності, а під час обговорення наявності морального життя в дитинки необхідно мати на увазі, переконані вчені, вплив спадковості. Звісно, що йдеться не про моральну свідомість, котра ще не може сформуватися протягом першого року життя, а про такі психічні прояви, які лише підготовляють матеріал для морального життя, які лише у світлі моральної свідомості, що сформувалася, виявляють у собі вищі або нижчі прагнення. Безпосередність свідомості дитинки не тільки не усуває нижчих рухів, а й видає їх. Якщо вдуматися в ранні прояви заздрості, ревнощів, гніву, егоїзму, жорстокості, то доводиться визнати, що вже на першому році життя в дітей $є$ елементарна, зародкова моральна свідомість у формі «моралі почуття». «Це означає, що ми не можемо, звичайно, називати «добрими» або «злими» душевні рухи, застосовуючи до наших понять, до нашої моральної свідомості, але повинні висвітлити їх тим, чим є вони для безпосередньої оцінки, до якої здатні вже й діти у формі почуттів. Тільки тому, що ті чи інші душевні рухи отримують моральну «розцінку» в дитячій душі, з її «мораллю почуттів», вони здатні стати матеріалом для несформованої моральної свідомості в повному розумінні слова», - пише В.В. Зеньковський [3, с. 99-100]. Виникнення моральної свідомості в жодному разі, переконаний професор, не може бути зведено до впливів дії соціального середовища; незважаючи на те що весь соціальний досвід дитини має величезний вплив на зміст уявлень і понять, сама функція моральної свідомості не могла б виникнути в такому порядку. Полярність хорошого і поганого, не маючи ще спеціального етичного сенсу, а виражаючи загальний для всього духовного життя момент - відмінність вищого й нижчого, кращого й гіршого, констатує В.В. Зеньковський, повинна вже певним чином вимальовуватися в дитячій свідомості як якась нечітка перспектива, куди принесе певну чіткість соціальний досвід дитини, адже справа в тім, що ця полярність ніяк не може розвинутися з полярності приємного та неприємного. Необхідно визнати, уважає професор, що як особлива форма життя й досвіду духовне життя починає функціонувати в психіці у формі суто емоційного передування майбутніх вищих проявів психіки. В.В. Зеньковський зауважує, що моральної свідомості як такої немає, але розкривається корінна протилежність вищого й нижчого, що знаходить у соціальному досвіді свою диференціацію та стимули для розвитку.

Отже, з філософсько-психологічних позицій моральне життя в дитині починається до формування моральної свідомості. Завдяки спадковості дитина народжується із цілою низкою нахилів, які визначають будову особистості, її активність; соціальна взаємодія вперше виявляє перед дитиною об'єктивні відлуння її активності. У філософській психології вважається, що саме реакції навколишніх людей надають дитині матеріал, на якому усвідомлюється спочатку нечітко полярність кращого й гіршого, вищого й нижчого. Соціальне середовище важливе тут як середовище, у якому отримують своє об'єктивне вираження та завершення внутрішні рухи: моральна свідомість у повній паралелі із самосвідомістю формується теж як проєктивне, але вона не творить себе одним соціальним досвідом, проявляючись у нечіткій формі почуття як непохідна, початкова функція. Отже, у нечіткій оцінці почуттів перед поглядом дитини на першому році життя вже вимальовується полярність вищого й нижчого, кращого та гіршого. Перші соціальні відлуння втілюють це почуття в деякі проєктивні етичні уявлення [2].

Отже, психічний і фізичний розвиток дитини передусім залежить від спадковості, тобто від батьків, а через них від низки попередніх поколінь. Тілесна спадковість також не викликає сумніву. Психічна спадковість вбачається, з одного боку, у загальній структурі особистості, в окремих психічних особливостях, аж до професійної обдарованості, з іншого боку, схожість батьків і дітей у їх психічних особливостях часто пояснюють однорідністю соціальних обставин, узагалі впливом соціальних умов. Стосовно не елементарних, а вищих сторін особистості заперечення факту психічної спадковості визнається помилковим. Отже, 
вищезазначене дає змогу стверджувати про генетичний принцип у філософській психології як один із методологічних прийомів у розумінні розвитку психіки людини.

Факт психічної спадковості представниками філософської психології кінця XIX - поч. XX ст. стоїть поза сумнівами $[1 ; 3 ; 6 ; 7]$. Це означає, що дитинка народжується з відомими нахилами та схильностями, яким вона слідує, завдяки психічній цілісності, але які природно викликають різноманітні соціальні відзвуки. Соціальне середовище розцінює особливості дитини, її схильності у світлі властивих їй моральних засад, а матеріалом для формування моральної свідомості дитини слугують безпосередні реакції навколишніх людей на її поведінку. Дитина дуже рано починає зважати на це; шляхи пристосування до того, чого від неї вимагають, відкриваються перед дитиною дуже рано. Отже, зміст морального на початку $€$ проєктивним у сенсі свого соціального походження, але це стосується тільки змісту, а не самої функції, яку виконує мораль, яка з'являється в психіці дитини з приводу тих чи інших даних досвіду, але не розвивається з них.

3 філософсько-психологічної позиції протягом першого року життя в дитячій свідомості вимальовуються перспективи прояву вищих психічних процесів, проступає в зародковій формі функція оцінювання, яка психічно реалізує прояв вищих процесів. «Ще живе дитя в «тумані», духовний зір розвивається дуже повільно порівняно з розвитком чуттєвого зору, але так само як у перші дні життя дитина стає здатна розрізняти між світлом і темрявою, так і здатність розрізняти між духовно-світлим і темним, вищим і нижчим уже прокидається в дитячій душі протягом першого року життя» [3, с. 105]. Це і є, переконаний В.В. Зеньковський, зачатки майбутнього духовного життя.

Зв'язку моральних почуттів із психічним розвитком людини у філософській психології кінця XIX - поч. XX ст. відводилася особлива роль. У духовному розвитку дитини моральні почуття, моральне життя, припускає В.В. Зеньковський, не має центрального значення, більш значущими визначаються естетичні устремління та переживання, але це стосується лише емпіричної сторони дитинства. «Якщо підійти глибше до дитячої душі, заглибитися, наскільки це доступно для нас, у метафізику дитинства, тоді стає зрозумілим, що моральне здоров'я дитячої душі $€$, можливо, найважливішим, найглибшим фактором її духовного розвитку», - пише професор [3, с. 181]. 3 емпіричного погляду у філософській психології визнається зародок естетичного життя в дитини в періоді раннього дитинства. Цілісність психіки дитини, iï наївність і безпосередність, що свідчать про відсутність у дитини будь-якого роздво- єння, штучності, характеризують справжнє моральне здоров'я психіки дитини. Найважливішим у моральних почуттях $€$ моральна чистота, щирість, простодушність і цілісність духу, у яких закладена головна моральна сила дитинства. «Якщо дитя має слабкий розвиток естетичного життя, релігійної сфери, але володіє моральною чистотою й цілісністю, ми повинні сказати про таку дитину, що вона не втратила образу Божого в собі, не втратила основну метафізичну силу своєї істоти», пише В.В. Зеньковський [3, с. 182].

3 філософсько-психологічного погляду кінця XIX - поч. XX ст. моральне дозрівання психіки дитини є віссю ї̈ духовного розвитку. У світлі зазначеного людина у своєму розвитку стоїть передусім і найбільше перед моральним завданням, і це завдання життєвого розвитку людини полягає для неї в тім, щоб віднайти належну їі індивідуальності ідеальну форму. Етичний ідеал не є єдиним для всіх, а для кожної індивідуальності є свій ідеал і, звісно, свій шлях до нього. У світлі етичного по-новому можна подивитися на нерівномірність і неправильність цього розвитку, недоліки та своєрідність індивідуальності (наприклад, упертість, апатія, лінь тощо). Дитина шукає свій шлях до свого ідеалу, а дорослі нав'язують їй свій ідеал і неодмінно бажають, щоб дитина рухалася саме за вказівкою дорослих. Представники філософської психології переконані, що моральні завдання, моральний сенс духовного дозрівання дитини є саме тим, що визначає логіку її розвитку, весь процес формування особистості в дитині. Дитинство $€$ певною фазою в духовному дозріванні дитини, яке триває протягом дитинства. Основна форма активності дитини пов'язана з іграми, і в них мають таке ж місце моральні рухи, як і реальна діяльність, навіть більше, ігри сприяють моральному розвитку дитини не менше, ніж безпосередня взаємодія із соціальним середовищем. Дитина вносить в ігри ту саму моральну настанову, як і в реальну активність, можливо, що грі належить найістотніша роль у ґенезі моральної свідомості. Уперше саме ігри відкривають дитині сферу можливого на противагу сфері дійсного, сферу бажаного на противагу сфері реального. Це має значення не тільки в інтелектуальному дозріванні, а й у розвитку моральної свідомості. У грі дитина має справу 3 об'єктом, створеним головним чином роботою уяви. Для всього духовного життя ця різниця не має значення: у грі дитина залишається $з$ тими самими завданнями, як і в реальній активності, зокрема в грі так само обов'язкові моральні вимоги, як і у звичайному житті. Моральна сфера поступово стає зосередженим носієм усвідомлення реальності, моральна активність приймає трудовий характер, і нерозрізнення реального й уявного 
стає небезпечним для здорового морального розвитку. Але для ранніх стадій морального життя це ще не має значення; усе духовне життя в ранньому дитинстві пов'язане з духовним життям у зрілому віці не як підготовка до активності й сама активність, а як різні сходинки в загальному розвитку духовного життя. Якщо на духовному житті в дитинстві неминуче позначаються загальні риси дитинства, то весь цей духовний зміст дитинства не може бути охарактеризований як нижча, попередня фаза духовного розвитку. Розвиток етичної, естетичної та релігійної свідомості, стверджує В.В. Зеньковський, несе із собою нові труднощі, але водночас він є фактором найважливішого в людині процесу - духовного дозрівання.

Завдання психології під час вивчення моральної сфери В.В. Зеньковський убачає не в аналізі й оцінюванні цілей морального розвитку ідеалів людини, а виключно лише у вивченні того, як розвивається, у яких формах складається моральне життя в людині. Для психології, зауважує професор, психічні прояви не є рівнозначними; вони різняться, зокрема, за продуктивністю та впливовістю, а моральні прояви оцінюються за вищими й нижчими проявами, здійснюючи розподіл із загальної етичної свідомості. «Саме психологічне вивчення морального розвитку, найкраще показує, як із туману, яким оповита дитяча душа, виступає для неї сонце свободи. Дитя поступово опановує моральну свободу, що властива їй із самого початку - і цей позаемпіричний момент входить у глибокій та інтимний зв'язок з емпіричним процесом, - зв'язок, який ми не можемо простежити в подробицях, але який із ще більшою наполегливістю повинні констатувати», - пише В.В. Зеньковський [3, с. 185-186]. Процес морального розвитку вже протягом раннього дитинства виявляється підпорядкованим двом типам закономірності: у ньому виказуються закони емпіричного світу та закони ідеального світу. Реальна й ідеальна сфера, емпірична й надемпірична дійсність непомітно входять у моральному (і взагалі в духовному) дозріванні дитини в глибокий зв'язок між собою.

Моральне життя в людині, згідно з філософською психологією, виражається й у прояві почуттів, і в роботі інтелекту, і в активності, бо моральне життя $є$ особливим типом світовідношення, цільною та своєрідною сферою життя в ній. Завдання психологічного розкриття моральної сфери в людині як особливої та цілісної форми життя ще не було правильно поставлено, а тим більше вирішено в психології в XIX ст. В.В. Зеньковський констатує, що й донині вирішення цього питання не дуже далеко відійшло від методологічних прийомів Адама Сміта (1723-1790), який відділив штучно «господарюючу людину» від людини мораль- ної. Незважаючи на великі успіхи, які досягнуті протягом XIX ст. в психологічній науці, вивченню моральної сфери приділялось недостатньо уваги. У психології дитинства цейштучний поділ є особливо умовний, але на рубежі $\mathrm{XIX}$ - XX ст. психологічне вивчення моральної сфери не могло відбуватися іншим шляхом.

Під час розвитку моральних почуттів виявляється моральна ідея. Моральне почуття оцінюється за підсумками. Незамінна роль моральних почуттів полягає в тім, що лише вони створюють безпосередню близькість людини до предмета моральної активності, привносять моральну свіжість, щирість у їі моральне життя. Проте розвиток моральної свідомості висуває небезпеку ослаблення моральних почуттів, бо моральна свідомість рухається до форми розумності, і людині дуже важливо усвідомити цю незамінну функцію почуттів у моральному житті. «Якраз у дитинстві ми й знаходимо переважно розвиток у моральній сфері почуттів; нехай моральний горизонт дітей вузький, нехай неясні, випадкові, мінливі їхні моральні поняття, але моральне ставлення дітей до людей, до природи таке простодушне, безпосереднє й сердечне, як це майже недоступно для нас», - пише В.В. Зеньковський [3, с. 187].

Основними моральними почуттями для представників київської школи філософської психології $є$ любов до людей (альтруїзм), сором і почуття сумління. Ці почуття привносять у внутрішній світ людини моральний досвід, створюють безпосереднє моральне орієнтування, надають моральну оцінку щодо трьох основних об'єктів морального життя -щодо самої особистості, щодо інших людей, щодо культури як системи життя, як до продукту активності. Переживаючи сором, людина безпосередньо розрізняє в собі, у своїй особистості позитивне та негативне. Тут людина переживає досить виражено все негативне в собі, а усвідомлення позитивного виступає лише як вторинне переживання. Зосередження на позитивному у власній особистості $€$ важливим для зростання й розвитку людини, проте не має переходити в самозакоханість, яка є симптомом морального занепаду.

Моральне орієнтування щодо оточуючих людей, установлення з ними відносин будуються на почутті тяжіння до них. Почуття любові до людей, співчуття є моральним завданням щодо інших людей. 3 одного боку, любов до людей і $€$ основним почуттям у цій групі почуттів: відкриває людині позитивне в інших, а не негативне; любов якщо не ідеалізує, то завжди пом'якшує не зовсім позитивні риси; з іншого любов до людей, бажання їм добра неминуче зіштовхує із заподіянням аморального. У любові до людей відкривається перше розрізнення позитивного та негативного в людях, визначається моральне завдання щодо них. У роботі 
совісті, яка в найпростіших своїх формах $€$ почуттям, хоча у вищих своїх формах вона має більш складний характер, людина оцінює не власну особистість, не інших людей, а власні дії як такі, у їх мотивах і в їх результатах. В.В. Зеньковський про почуття совісті зазначає таке: «Робота совісті пробуджується саме тим, що сходить із насіння, яке ми сіємо, тим, що існує вже як невиправний, недосяжний факт, що входить в об'єктивну дійсність» [3, с. 188].

Отже, саме завдяки таким почуттям, як сором, любов до інших людей, робота совісті, у свідомості людини формується моральний досвід. Завдяки переживанням людиною цих почуттів перед нею виступають три об'єкти моральної оцінки, три сфери моральної активності людини: її особистість, інші люди, культура як продукт спільної діяльності людей.

Що стосується почуття обов'язку, основне значення якого для моральної сфери особливо підкреслював Іммануїл Кант (17241804), з позицій філософської психології це почуття є продуктом, а не джерелом морального життя в людині, і в психології розвитку психіки дитини це можна чітко простежити.

Провідником у моральну сферу дитини в ранньому періоді визнається почуття сорому у вузькому сенсі. Розвивається це почуття досить повільно, адже дітям немає чого соромитися в собі, тому почуття сорому для свідомості дитини морального сенсу набуває приблизно до кінця раннього дитинства. До цього сором починається з первинної сором'язливості, позбавленої морального змісту для самої дитини. Лише тоді, переконаний В.В. Зеньковський, коли вже сформувалося суб'єктивне самоусвідомлення, уможливлюється дія сорому в бік розвитку моральної свідомості. Психологічна дія соціального сорому виникає на базі індивідуального сорому, але незалежно від цього соціальний сором має вагоме значення під час формування в людини моральної свідомості, констатує професор, бо соціальний сором уводить дитину у світ моральної традиції, у моральне мислення оточуючих, привчає рахуватися з об'єктивною, зовнішньою стороною вчинків людини, усієї її поведінки. Завдяки саме соціальному сорому дитина вперше починає відчувати моральну дійсність поза собою, моральну атмосферу, починає усвідомлювати, що моральне життя $€$ щось спільне, для всіх обов'язкове, не є щось випадкове й суб'єктивне. Соціальний сором змушує дитину думати про цю надіндивідуальну інстанцію, і так поступово над внутрішнім світом дитини з'являється деяка моральна інстанція, яка спочатку втілюється в суспільстві, у його моральних звичаях.

Індивідуальний сором у своїй чистій формі не однаково в усіх відіграє значну роль у розвитку моральної свідомості. Індивідуальні від- мінності тут дуже значущі, крім того, що інтерес до самої себе $є$ явищем більш пізнім і здебільшого буває забарвленим односторонньо: слабкість сорому як провідника моральної енергії в дітях пояснюється, як уже зазначено, його зосередженістю на неналежному, поганому. Сором - болісне відчуття, і тому має велику психічну силу, але в ньому немає творчого піднесення, а $€$ втеча від самого себе. Сором нерідко призводить до моральної депресії, і лише в психічній обстановці морального здоров'я він набуває творчого значення.

Почуття любові у філософській психології має також своє роз'яснення. Стверджується, що якщо дорослі висловлюють свої почуття це не викликає ніяких почуттів у дитини; але якщо дитина помічає сама страждання - чує його в голосі, бачить у виразі обличчя, у сльозах тощо, то починає переживати жалість. Із філософсько-психологічних позицій це означає, що почуття любові в дітей до людей має безпосередній і навіть, можна сказати, сенсуальний характер. Прояви любові в дитини абсолютно не пов'язані із соціальними перепонами. Дитині соціальні відмінності не заважають усюди бачити людину.

Що стосується прояву сумління, то в простішій формі воно виступає у формі почуття, поступово розвиваючись у більш складну форму. Сумління спрямовує оцінку людини не на власну особистість як таку, а на активність у її результатах та об'єктивних підсумках. Психологія роботи сумління кінця XIX - поч. XX ст. $€$ вивченою недостатньо, переважно розглядається в негативній формі, тобто в указівках того, чого не можна робити, ніж того, що має бути. В.В. Зеньковський вважає: «Робота сумлінняєцентральним руслом, яким струмує в нас моральний досвід, бо тут із більшою силою, ніж в інших випадках, моральна оцінка прагне від форми почуття перейти до форми судження. Моральна свідомість тут зріє з найбільшою силою, бо хоча робота сумління завжди залишається зверненою до суб'єкта, але в суб'єкті вона висвітлює не мотиви його дій, не особисті відзвуки їх у тих, до кого вони звернені, а цінність дії самої по собі» [3, с. 192]. Сумління визнається найбільш впливовою та суттєвою стороною в моральній свідомості людини.

У дитини робота сумління, як і переживання сорому, проходять свою проєктивну стадію, котра спирається на дещо загальне, недиференційоване усвідомлення власного неправильного. За положеннями філософської психології означеного періоду, уважалося, що робота сумління починається раніше від прояву сорому; діти дуже рано засвоюють внутрішній зв'язок між «проступком» і «покаранням». Звичайно, робота совісті, усвідомлення неправильного оформляється завдяки соціально-психічному тиску, що утворює сут- 
ність будь-якого «покарання», але цей тиск не створює роботу совісті, а лише ії оформлює. Дитина дуже рано, фактично ще в грудному періоді, уже є чутливою й до позафізичного впливу, і це свідчить про їі моральну чутливість, про здатність засвоювати під час впливу на неї моральну сторону. Достатньо порівняти нормальних дітей із морально тупими, констатує В.В. Зеньковський, щоб погодитися з тим, що засвоєння морального сенсу покарання не $€$ справою інтелекту, а спирається на ту особливу роботу, оформлені підсумки якої вбачаються як усвідомлення «гріха» [4].

Висновки 3 проведеного дослідження. Моральна свідомість дитини спочатку виступає лише у формі безпосередніх оцінок почуття, але саме цей моральний досвід робить дитину здатною не просто засвоювати правила життя й соціальні традиції. Для дитини моральна сторона усвідомлюється завдяки змісту соціальних традицій: самі форми взаємин, самі шляхи діяння підказуються їй традицією, указівками старших, і в цьому сенсі моральне життя дитини має гетерономний характер, але без роботи моральних почуттів усе це не мало б морального сенсу для дитини. I лише усвідомлення цього дасть змогу зрозуміти справжній сенс дитячого морального життя. Вона має гетерономний характер, тобто визначається в змісті й навіть у своїй санкції всім тим, що лежить поза особистістю дитини - традицією, звичаями, авторитетом дорослих. Але дитина не просто робить те, що наказує ій традиція, авторитет батьків, дитина засвоює, тобто робить своїм зміст моралі, яка панує в житті. Чи потрібна мораль, яким має бути її побудування - усі ці питання не займають свідомість дитини. Проте, згідно з філософсько-психологічною традицією, якщо б дитинка не мала власного морального матеріалу, хоча він і нечіткий, розуміння чужих ідей морального змісту для неї було б неможливим, бо саме цей власний моральний матеріал уводить дитину у світ моральних взаємин.

Моральна перспектива відкривається для дитини через ту моральну роботу, яка пов'язана з безпосередніми оцінками в її почуттях. I тут повторюється те загальне положення з філософської психології, яке не раз доводиться повторювати під час аналізу дитячої свідомості: проєктивний матеріал не створює психічної функції, а вперше її оформлює, надає їй уперше певного змісту.

\section{ЛІТЕРАТУРА:}

1. Гогоцкий С.С. Введение в педагогику. 2-й вып. Киев : В Унив. тип., 1882. 84 с.

2. Джеймс У. Многообразие религиозного опыта. Санкт-Петербург : Андреев и Сыновья, 1992. 418 с.

3. Зеньковский В.В. Психология детства. Лейпциг : Сотрудник, 1924. 348 с.

4. Зеньковский В.В. О иерархическом строении души. Научные труды русского народного универcumema в Праге. Прага, 1929. Кн. 2. С. 3-46.

5. Ждан А.Н. История психологии: от Античности до наших дней : учебник для вузов. 10-е изд., испр. и доп. Москва : Академический проект ; Трикста, 2018. 587 C.

6. Сикорский И.А. Душа ребенка: с кратким описанием души животных и души взрослого человека; с 20-ю рисунками. 3-е изд., доп. Киев : Типография С.В. Кульженко, 1911. 192 с.

7. Челпанов Г. Что нужно знать педагогу из психологии. Вопросы фрилософии и психологии. 1911. № 1. Кн. 106. С. 38-69. 